\title{
Políticas Públicas de Proteção à Vítima: uma Proposta de Arranjo Institucional de Segurança PÚBLICA
}

\author{
Antonio Henrique Graciano Suxberger* \\ Mayara Lopes Cançado**
}

\begin{abstract}
1 Introdução. 2 Desenvolvimento. 2.1 Aproximação conceitual de Vitimologia e sua conformação no Direito brasileiro. 2.2 Os direitos das vítimas de crime e o atual estado de coisas da legislação federal na última década. 2.3 Aproximação das políticas públicas: atores e planos de realização. 2.4 Arranjo institucional e um estreito diálogo interorganizacional. 2.5 Integração operacional que reclama políticas de Estado. 3 Conclusão. Referências.
\end{abstract}

\section{RESUMO}

O presente artigo analisa a orientação legislativa na última década quanto à conformação das políticas públicas de proteção à vítima no processo penal. A pesquisa menciona a relevância de se observar essas políticas públicas sob a perspectiva de um arranjo institucional de segurança pública, em que o sistema de justiça criminal não atua de forma exclusiva. O estudo observa revisão bibliográfica e documental da doutrina pátria sobre o tema, abordando aproximações conceituais da Vitimologia e de Políticas Públicas. O artigo revisita os principais direitos das vítimas no processo criminal para cotejá-los com a contribuição das políticas públicas, especialmente em relação à conformação dos atores e dos planos de realização das políticas públicas atinentes à vítima de delito. A importância do trabalho reside na compreensão de que as políticas públicas de promoção dos direitos assegurados à vítima no processo penal reclamam políticas de Estado, por meio de uma integração operacional e de um estreito diálogo interorganizacional dos atores de segurança pública.

Palavras-chave: Políticas Públicas. Vitimologia. Arranjo institucional.

* Doutor em Direitos Humanos e Desenvolvimento pela Universidade Pablo de Olavide. Mestre em Direito pela Universidade de Brasília. Professor do Programa de Mestrado e Doutorado em Direito do Uniceub/DF. Professor do Máster em "Derechos Humanos, Interculturalidad y Desarrollo" e Professor Associado da linha de investigação "Derechos Humanos y Desarrollo" do programa de Doutorado em Ciências Jurídicas e Políticas da Universidade Pablo de Olavide (Sevilha, Espanha). Promotor de Justiça no DF. E-mail: <suxberger@gmail.com>.

Graduada em Direito pelo Centro Universitário do Distrito Federal - UDF (2011). Pós-graduada em Ordem Jurídica e Ministério Público pela Fundação Escola Superior do Ministério Público do Distrito Federal e Territórios - FESMPDFT (2016). Atualmente é servidora do Ministério do Trabalho e encontra-se cedida ao Superior Tribunal de Justiça. E-mail: <mayacancado@gmail.com>. 


\section{INTRODUÇÃO}

No cenário acadêmico atual, é possível constatar que as políticas públicas não fazem parte da maioria dos currículos de graduação nem das pós-graduações em Direito. O ensino jurídico brasileiro, há quase dois séculos, "não se propôs, especificamente, a formar profissionais do direito preparados para estruturar, operar e aprimorar políticas públicas e programas de ação governamental". ${ }^{1}$ A despeito das inúmeras dificuldades conceituais, metodológicas ou empíricas, é perceptível a necessidade de se explorar as interações entre o Direito e as Políticas Públicas, principalmente por se tratar de uma área sensível, ainda incipiente aos juristas e de nítida preocupação prática ao que se discute no Direito.

A eleição das políticas públicas de proteção à vítima como objeto de estudo dá-se por força da carência de estudos jurídicos na área da implementação de políticas públicas. É possível constatar a limitação, do ponto de vista acadêmico, de recursos metodológicos para uma melhor conexão entre o Direito e as Políticas Públicas. Essa deficiência acadêmica dificulta a formação de profissionais preparados para atuarem como possíveis gestores públicos. O Direito, é certo, volta-se à necessidade de acolher a contribuição da Vitimologia para o desenho institucional de suas estruturas de funcionamento. No entanto, a preocupação dirigida a um conhecimento jurídico aplicado é reflexo da relevância - ou mesmo da urgência - a que a abordagem jurídica igualmente se dedique ao modo pelo qual as prescrições jurídicas assumem contornos práticos, isto é, ao modo pelo qual as ações de Estado asseguram a materialização da opção positivada juridicamente de proteção ou garantia desse ou daquele direito.

Quanto aos reclamos de Vitimologia, é possível observar que, apesar de a última década trazer diversos aportes legislativos a respeito do tema, há uma carência de estudos que tratem do assunto de forma clara e sistemática. Por esse motivo, o artigo visa a contribuir com uma abordagem crítica do atual estado de coisas da legislação e sua conformação empírica.

As políticas públicas substanciam a convergência entre o funcionamento do governo e a formação dos arranjos institucionais. A essa preocupação se refere a chamada "política jurídica", ocupada da compreensão do fenômeno governamental dentro ou a partir do direito. $\mathrm{O}$ estudo das políticas públicas, nessa toada, nada mais é que uma aproximação da tecnologia jurídica incidente na realização do Estado. ${ }^{2}$

A categorização da dogmática jurídica, tal como realizada por Albert Calsamiglia, ${ }^{3}$ mostra-se igualmente útil. Ao apresentar três diferentes estilos de conformação da dogmática jurídica, Calsamiglia destaca a ciência, reputada como "pura" e situada no debate epistemológico de afirmação do direito; a técnica, esta, orientada precipuamente pela pragmática e pelos meios próprios de realização e manifestação do direito; e, finalmente, a tecnologia jurídica. Esta última cuidaria da visualização dos arranjos, dos sujeitos e dos instrumentos próprios de realização do direito. 
O estudo das políticas públicas - de viés instrumental analítico, por isso afirmado como "tecnologia jurídica" - resolve-se no debate sobre os arranjos institucionais necessários à implementação das garantias jurídicas positivadas. Trata-se, assim, de identificar, sistematizar as condições, as regras e as instituições jurídicas necessárias a um Estado em desenvolvimento para formular e executar políticas públicas, criando canais e processos de organização das forças da sociedade.

Nesse sentido, é possível citar uma inovação na legislação quanto à fixação dos atores de sistema de justiça como atores de realização responsáveis pela implementação de políticas públicas de garantia à vítima, com a previsão de um diálogo interorganizacional, por meio de um arranjo institucional. Entretanto, esses atores se deparam com dificuldades teóricas e práticas no momento de dar cumprimento às disposições legislativas. Essa complexidade, não raro, pode gerar um esvaziamento semântico das previsões legislativas e desestimula os gestores públicos.

Dessa forma, é com base nessas avaliações que a pesquisa a ser desenvolvida pretende aprofundar o conhecimento acadêmico sobre o tema. Além disso, o estudo contribuirá para uma abordagem aplicada a respeito do motivo pelo qual as previsões legislativas acerca das reivindicações de Vitimologia possivelmente carecem de eficácia.

O estudo observará revisão bibliográfica e análise documental da doutrina pátria sobre o tema e tomará como amostra a legislação federal promulgada e publicada no decorrer da última década (2006 - 2016), mais especificamente as leis federais que versem sobre proteção à vítima no processo penal, com uma abordagem crítica e minudenciada das previsões legislativas e suas respectivas propostas de alteração na inclinação legislativa.

Inicialmente, é apresentada uma abordagem conceitual de Vitimologia e sua conformação no direito brasileiro, com uma aproximação conceitual do termo vítima de delito. Seguidamente, o artigo explorará a compreensão das vitimizações causadas direta e indiretamente pela prática criminosa, identificará os principais direitos das vítimas de crime e exporá o atual estado de coisas da legislação federal na última década. Em sequência, pretende-se uma aproximação das políticas públicas, com especificações de alguns atores e planos de realização delas atinentes à vítima no processo penal. Buscam-se, como base, as interações existentes entre o Direito e as Políticas Públicas, a partir da perspectiva dos papéis do Direito e dos juristas nas políticas públicas e da importância de um ensino jurídico acadêmico que englobe o campo das políticas públicas. Por fum, propõe-se um arranjo institucional com um estreito diálogo interorganizacional para a implementação de políticas públicas de proteção à vítima de delito, demonstrando a necessidade de ações que reclamam políticas de Estado. 


\section{DESENVOLVIMENTO}

Para o desenvolvimento do presente artigo, impõe-se a compreensão da própria Vitimologia e sua contribuição para o desenho das políticas públicas de acolhimento e proteção à vítima no processo criminal. O estudo, pois, dos diplomas legais dirigidos a ações de proteção das vítimas, na última década, é exemplificativo da preocupação de atuação articulada e conjunta dos atores estatais incumbidos tanto do programa político-criminal do Estado quanto das ações dirigidas à segurança pública. A abordagem dos atores e dos planos de realização das políticas públicas mostra-se, então, tema indissociável dessa problematização, para permitir a afirmação da necessidade de uma atuação integrada e de arranjos institucionais adequados à concretização das prescrições normativas.

\subsection{APROXIMAÇÃO CONCEITUAL DE VITIMOLOGIA E SUA CONFORMAÇÃO NO DIREITO BRASILEIRO}

Primeiramente, optando-se por não abordar as discussões doutrinárias quanto à origem da Vitimologia como uma ciência e sua consequente evolução histórica, importa destacar as três fases peculiares que demonstram a importância da vítima no processo penal: fase protagonista, fase de neutralização e fase da redescoberta. ${ }^{4} \mathrm{O}$ protagonismo da vítima se refere à fase da vingança privada, em que, preteritamente, a própria vítima dava ensejo à persecução penal e à imposição de um castigo. Em contrapartida, na neutralização, o ius puniendi passou à titularidade estatal, o que substituiu a outrora vingança privada por uma verdadeira resposta pública. E, finalmente, há a redescoberta, fase em que a Vitimologia se desenvolveu paralelamente a uma extensa cadeia de políticas sociais em favor das vítimas, por exemplo, programas de assistência, reparação, compensação e tratamento.

A passagem da fase de neutralização para a fase da redescoberta, sob o enfoque do movimento vitimológico, destaca-se no tocante a uma abordagem conceitual do termo vítima. Dentre os diversos conceitos possíveis, ressalta-se o conceito jurídico-penal, sob o prisma das interações da Vitimologia e as suas consectárias reformulações.

Interessa revisitar o conceito de vítima de delito quanto ao seu aspecto jurídico, restrito à área criminal, em que a vítima penal é a pessoa atingida pela ofensa de terceiro a uma norma jurídica de direito penal, a qual poderá sofrer algum prejuízo, dano ou lesão decorrente de prática criminosa. A concepção criminológica da vítima escapa do recorte do presente estudo, por considerar o crime como fenômeno da realidade, fruto de condições sociológicas dentre outras peculiaridades e não examinar a vítima em face da violação de uma norma, de uma lei.

A Organização das Nações Unidas (ONU) passou a demonstrar interesse pelo tema em 1980, ocasião em que foi elaborada a Declaração dos Princípios Básicos de Justiça Relativos às Vítimas da Criminalidade e de Abuso de Poder, ${ }^{5}$ a qual se ateve a dois tipos específicos 
de vítimas: as vítimas de delito e as vítimas de abuso de poder. No tocante às vítimas de delito, a declaração da ONU as conceitua:

1. Entendem-se por "vítimas" as pessoas que, individual ou coletivamente, tenham sofrido um prejuízo, nomeadamente um atentado à sua integridade física ou mental, um sofrimento de ordem moral, uma perda material, ou um grave atentado aos seus direitos fundamentais, como consequência de atos ou de omissões violadores das leis penais em vigor num Estado membro, incluindo as que proíbem o abuso de poder.

2. Uma pessoa pode ser considerada como "vítima", no quadro da presente Declaração, quer o autor seja ou não identificado, preso, processado ou declarado culpado, e quaisquer que sejam os laços de parentesco deste com a vítima. O termo "vítima" inclui também, conforme o caso, a família próxima ou as pessoas a cargo da vítima direta e as pessoas que tenham sofrido um prejuízo ao intervirem para prestar assistência às vítimas em situação de carência ou para impedir a vitimização. ${ }^{6}$ (Grifamos).

Com base na definição fornecida pela ONU, é possível constatar que o conceito de vítima vai além da pessoa diretamente afetada pelas consequências do delito, podendo incluir tanto a família quanto as demais pessoas indiretamente afetadas, por exemplo, terceiros que intervêm para proteger a vítima ou para prevenir que ocorra a vitimização. Desse modo, entende-se como vítima o sujeito passivo eventual da prática criminosa, isto é, quem sofre os efeitos negativos da ação delituosa, com especial proteção do legislador. A identificação desse sujeito passivo eventual depende de cada caso concreto, levando em consideração o objeto jurídico do crime e o interesse protegido penalmente. Entretanto, há também o denominado sujeito passivo constante, presente em todos os crimes: o Estado, o que justifica a sua legitimação para a persecução penal na grande maioria dos crimes. Posto isso, utilizaremos a expressão vítima como sinônimo de sujeito passivo eventual.

A vítima é, sem dúvida, o sujeito mais frágil em todo o sistema de justiça criminal - motivo pelo qual necessita de especial atenção. Maia Neto, ao mencionar o fracasso do sistema penal em reparar, prevenir e alcançar o objetivo da reintegração social, afirma que, para uma visão mais moderna, a principal missão da Justiça criminal é "reparar e indenizar as vítimas de crime, posteriormente, secundária ou paralelamente, à punição do autor do ilícito". ${ }^{7}$ Entretanto, a finalidade do Direito Penal que tem ganhado mais destaque é a da dupla função preventiva, fornecida por Ferrajoli: ${ }^{8}$ a prevenção de delitos e a prevenção de penas arbitrárias ou desmedidas contra o autor da infração.

A título ilustrativo, um exemplo se presta a essa constatação, no tocante aos efeitos da condenação penal. $\mathrm{O}$ art. 91 do Código Penal prevê, como efeito secundário da condenação, o dever de reparar o dano, além de tornar certa a obrigação de indenizar os prejuízos. Contudo, a reparação de danos às vítimas deveria ser efeito primário, mais relevante ou tanto 
quanto a própria pena privativa de liberdade. Nesse sentido, é possível mencionar a atual tendência despenalizadora trazida pela Lei 9.099/95, ${ }^{9}$ que, além de dispor sobre os Juizados Especiais, valoriza a reparação da vítima como condicionante ou indicadora da desnecessidade da persecução penal.

Além disso, há a necessidade de um amparo mais efetivo à vítima e menos meramente teórico, em prol da humanização do processo penal, com foco em um conflito humano, regado de soluções reais, atento aos problemas, aos anseios e aos interesses das pessoas reais envolvidas, em detrimento de uma mera resposta jurídico-formal. No entanto, o atendimento processual dispensado à vítima, muitas vezes, mostra-se potencialmente hábil a lhe causar tantos ou mais males do que a própria prática do crime, ensejando assim um novo processo de vitimização. Com enfoque na proporção do fenômeno vitimal e nas suas consequências para a vítima, a doutrina passou a classificar os distintos processos de vitimização sob três aspectos específicos: vitimização primária, vitimização secundária e vitimização terciária.

No tocante aos graus de vitimização, o primeiro dano está exclusivamente associado à prática de uma conduta típica prevista como infração penal e a sua subsunção à norma penal repressora; dito de outra forma, a vitimização primária resulta diretamente do crime e causa danos diversos, como materiais, físicos, psicológicos. Já a vitimização secundária ou sobrevitimização ${ }^{10}$ se refere aos danos causados pela atuação das instâncias formais de controle, mais especificamente, pelo sistema de justiça criminal, nos quais se incluem policiais, juízes, promotores, peritos, serventuários da justiça, como participantes do processo penal e os primeiros a terem contato com a vítima após a ocorrência do fato delituoso. Essa sobrevitimação tende a agravar as consequências da vitimização primária, devido ao fato de o sistema de justiça penal possuir a atuação voltada ao delinquente e à investigação, geralmente sem orientação vitimológica.

Imagine-se uma vítima de estelionato que procura uma delegacia de polícia para prestar um boletim de ocorrência e obter informações. Normalmente, o agente de polícia faz o atendimento, anota as informações que entende como relevantes para o deslinde do caso e dispensa a vítima, sem lhe prestar maiores informações a respeitos dos procedimentos e ações para reaver os valores extraviados. Nesses casos, muitas vezes, o sofrimento da vítima é esquecido. Não há uma maior preocupação com suas expectativas e suas necessidades. A grande demanda de questões policiais faz que o fato, de suma importância para vítima, se torne corriqueiro para os policiais. Esses, não raro, deixam de dar a devida atenção à vítima como sujeito de direitos; a vítima, então, passa a ser objeto de investigação. Além de a vítima se sentir "culpada" por ter se deixado levar pela fraude, ela se sente desrespeitada e frustrada com a atuação das instâncias de controle.

Fernandes conceitua vitimização secundária como "resultante do indevido funcionamento do sistema processual e da irregular atuação da máquina policial ou judiciária”. ${ }^{11}$ Assim, é possível afirmar que essa vitimização é mais preocupante do que a própria vitimi- 
zação primária, especialmente pela sensação de desamparo e frustração causada na vítima; por esta, em tese, esperar que as instâncias de controle não só respeitem como também resguardem seus direitos, outrora atingidos e prejudicados com a ocorrência do delito. Essa falta de preocupação demonstra um desvirtuamento de finalidade na atuação jurisdicional, gerando uma grave perda de credibilidade nas instâncias formais de controle. Por sua vez, a vitimização terciária emerge da falta de amparo do Estado e da ausência de receptividade social, mediante o contato da vítima com o seu meio ambiente social ou grupo familiar, no trabalho, na escola, na igreja ou em qualquer outro convívio social; esse tipo de vitimização é resultante do desamparo de assistência pública e social. Normalmente, o medo da rotulação, não raro, faz que a vítima sofra novamente um dano, uma vez que se vê compelida a não tornar pública a ocorrência do crime.

O enfoque deste estudo compreende a análise da vitimização secundária, com algumas nuances da terciária, abordando possíveis prevenções no âmbito das políticas públicas, por meio de um arranjo institucional de segurança pública.

\subsection{OS DIREITOS DAS VÍTIMAS DE CRIME E O ATUAL ESTADO DE COISAS DA LEGISLAÇÃO FEDERAL NA ÚLTIMA DÉCADA}

Com o propósito de sistematizar os principais direitos e garantias das vítimas tutelados no ordenamento jurídico processual penal brasileiro, destacam-se quatro vertentes de direitos vitimais: direito à proteção, direito à informação, direito à participação e direito à solução consensual do processo. Dentre essas quatro vertentes, interessa revisitar o direito de proteção da vítima em sua acepção mais restrita, o qual tem como objetivo promover o retorno da vítima à sua posição anterior ou diminuir, tanto quanto possível, os efeitos danosos causados pela ocorrência da infração penal. Em resumo, a atual legislação processual penal brasileira dispõe sobre cinco novas perspectivas ao direito à proteção: direito a um tratamento respeitoso, direito à proteção da segurança, direito à proteção da privacidade, direito a uma assistência multidisciplinar (médica, psicológica, social, jurídica) e direito ao amparo econômico do Estado. ${ }^{12}$

A Lei 11.690/2008 ${ }^{13}$ conferiu nova redação ao artigo 201 do Código de Processo Penal e reconheceu vários direitos em prol da vítima, especialmente no tocante ao direito de proteção. Esse artigo prevê, no $\S 4^{\circ}$, o direito à separação física do acusado por ocasião da instrução; já o $\S 5^{\circ}$ estabelece tanto o atendimento multidisciplinar, especialmente nas áreas psicossocial, jurídica e de saúde, quanto o direito à assistência jurídica no âmbito do processo criminal, ambos às expensas do Estado ou do autor do delito. Por fim, o $§ 6^{\circ}$ dispõe sobre o direito às providências necessárias para a preservação da honra, da privacidade e da imagem no curso do processo.

Entre as perspectivas do direito à proteção da vítima mencionadas, destaca-se o direito à proteção da honra, da imagem e da privacidade em face da publicidade ampla prevista, 
como regra, no processo penal. Essa publicidade exerce o papel de garantia de garantia ou garantia de segundo grau, ${ }^{14}$ de modo que possibilita o monitoramento do respeito às garantias primárias e assegura a transparência da atividade jurisdicional, além de afastar a desconfiança da população quanto à Administração da Justiça. Entretanto, a publicidade não é uma garantia de caráter absoluto ou tida como inafastável no âmbito do processo penal. Em algumas situações, o interesse público à informação deve ceder em virtude do interesse privado de caráter preponderante no caso concreto. Exemplo dessa mitigação dá-se com a Lei 12.015/2009, ${ }^{15}$ que acrescentou o art. 234-B ao Código Penal. A modificação legislativa objetivou claramente o resguardo da intimidade da vítima de crimes contra a dignidade sexual, por meio da imposição da obrigatoriedade de segredo de justiça, isto é, publicidade restrita ou interna.

Essa ponderação de garantias visa a mitigar a superexposição midiática, que coleciona casos de abuso do direito à informação, provavelmente devido à busca desmedida de relatos e ao excesso de curiosidade. Entende-se por superexposição midiática o fato de a vítima ficar demasiadamente exposta ao meio social, em razão da repercussão que pode ensejar a prática da infração penal, além de consistir em uma forma de constrangimento causadora dos danos decorrentes das citadas vitimizações secundária e terciária; tornando-se, portanto, necessária à tutela estatal.

Veja-se que a proteção da vítima, nesse ponto, caminha pari passu com a tutela do próprio acusado. Na expressão de Eleonora Rangel Nacif, a indevida publicidade dos fatos que estão sob sigilo acaba transformando o suspeito em indiciado, o indiciado em denunciado, o acusado em condenado. Da existência de indícios passa-se rapidamente à afirmação contundente de que a prova é robusta, e, assim, quem deveria presumir-se inocente é prontamente culpado. "É o famoso julgamento do fato e da pessoa pela mídia e pela opinião formada por esta". ${ }^{16}$

A Lei 11.690/2008 ${ }^{17}$ também promoveu importante alteração em relação ao direito à informação da vítima. Esta, independentemente de sua habilitação como assistente, deve ser comunicada a respeito dos seguintes eventos ocorridos no curso do processo: entrada e saída do acusado da prisão, designação da data para realização da audiência, prolação da sentença ou do acórdão respectivo que a mantenha ou modifique. A inclusão dessa série de direitos outrora não conferidos à vítima demonstra uma maior preocupação do legislador com a figura do ofendido. A sua participação não mais se restringe a fornecer elementos de prova. Os atores do sistema de justiça criminal possuem a responsabilidade de não só incluir a vítima, mas de mantê-la informada de todos os atos do processo. A alteração promovida, na medida em que assegura ao particular atingido pela ação criminosa e credor da resposta estatal algum tipo de satisfação, fomenta verdadeiro accountability institucional - responsabilização, obrigação, prestação de contas - para com o sujeito de direitos mais sensíveis da persecução criminal. 
A Lei 11.719/200918 concedeu nova redação ao inciso IV do art. 387 do Código de Processo Penal, possibilitando ao juiz, por ocasião da sentença penal condenatória, fixar valor mínimo para reparação dos danos causados pela infração penal. A alteração legislativa não cria propriamente uma ação civil cumulada com uma ação penal no juízo criminal, pois a possibilidade de pronta fixação de indenização substancia apenas efeito da sentença condenatória. Convém lembrar que, relativamente à pretensão de reparação ou compensação pelo dano causado à vítima por força da ação criminosa, vigora entre nós o sistema da independência das instâncias, isto é, não há estrita vinculação ou dependência entre a ação penal e a ação de reparação e/ou compensação do dano à vítima. Por isso, a possibilidade da antecipação da fixação de valor indenizatório pelo juízo criminal não inibe ou não impede o manejo da ação civil ex delicto. ${ }^{19}$

Os artigos 63 e 64 do Código de Processo Penal preveem duas opções para que o ofendido possa buscar o ressarcimento do dano causado pelo delito: a ação de execução ex delicto, de natureza executória, pressupõe a existência de um título executivo, consubstanciado na sentença penal condenatória com trânsito em julgado; e a ação civil ex delicto, proposta no âmbito cível, de natureza cognitiva e independente da ação criminal. ${ }^{20}$ No primeiro caso, a vítima se vale da sentença condenatória para liquidá-la na esfera cível e, na sequência, promover os atos de execução para indenização do prejuízo experimentado por força do crime. No segundo caso, de espectro mais amplo, permite-se que a discussão seja conduzida, inclusive, para a eventual compensação (e não só reparação) dos danos experimentados pela prática criminosa, a abranger, portanto, a possibilidade de danos morais ou mesmo outros danos que extrapolem a simples recomposição patrimonial do ofendido.

Além das alterações normativas já mencionadas, algumas outras leis que promoveram direta ou indiretamente a proteção e os direitos das vítimas foram publicadas no decorrer dos últimos dez anos. Destacam-se a Lei 12.415/2011 ${ }^{21}$ que autorizou a fixação de alimentos provisórios em favor de criança ou adolescente dependentes de agressor que seja afastado da moradia comum por determinação judicial, a Lei 12.461/2011,22 que estabeleceu a notificação compulsória dos atos de violência praticados contra idoso atendido em serviço de saúde, a Lei 12.483/2011, ${ }^{23}$ que instituiu o Programa de Assistência a Vítimas e a Testemunhas, e a Lei 12.845/2013, ${ }^{24}$ que determina atendimento obrigatório e integral de pessoas em situação de violência sexual.

Contudo, para além das alterações pontuais realizadas por esses diplomas legais, faz-se necessário revisitar, de forma mais minudenciada, a Lei 11.340/2006, ${ }^{25}$ conhecida como Lei Maria da Penha, bem como a Lei 11.530/2007, ${ }^{26}$ que institui o Programa Nacional de Segurança Pública com Cidadania - Pronasci. Ambos os diplomas versam de forma mais específica sobre políticas públicas (planos, programas, projetos, ações) atinentes à proteção da vítima de crime e à prevenção de delitos.

A Lei 11.340/2006 27 trouxe um arcabouço de medidas assecuratórias à mulher, com potencial de produzir importantes impactos sociais para o enfrentamento da violência doméstica 
e familiar. Entretanto, essa lei não obteve, de imediato, efetividade prática, devido ao pouco preparo dos órgãos de segurança pública e do sistema de justiça criminal para abordagem própria e específica desse tipo de violência, que vai muito além da simples correspondência com os tipos penais da legislação comum. A Lei Maria da Penha traduz uma opção evidente por um marco normativo protetivo da mulher em situação de violência doméstica e familiar. Não se trata de um diploma legal com preceitos penais ou processuais apenas, mas de uma maneira específica de realização da intervenção do Estado por sua ferramenta mais dura de controle social: o Direito Penal. A Lei 11.340/2006 reúne "um conjunto de preceitos normativos que estabelecem aprioristicamente a necessária consideração do contexto histórico e social de violência de gênero vivenciado no país”. ${ }^{28}$ As disposições dessa Lei vão muito além do jurídico. A temática da violência doméstica e familiar pede uma sofisticada interação dos arranjos institucionais do Estado brasileiro. As políticas públicas materializam a convergência entre o funcionamento dos órgãos de Estado e a formação de seus respectivos atores. A inovação trazida pela Lei 11.340/2006, especialmente em relação à vítima, dá-se no campo da "política jurídica", justamente por manifestar preocupação com a compreensão do fenômeno governamental dentro ou a partir do direito. ${ }^{29}$

O advento da Lei 11.530/200730 impactou, entre outros pontos, na implementação de políticas públicas para efetivação das disposições da Lei Maria da Penha. Ao positivar o Programa Nacional de Segurança Pública com Cidadania - Pronasci, a Lei 11.530/2007 buscou articular políticas de segurança com ações sociais; privilegiou a prevenção e centrou-se na consideração das raízes da violência, sob o enfoque da valorização dos profissionais de segurança pública, da reestruturação do sistema penitenciário, do combate à corrupção policial e do envolvimento da comunidade na prevenção da violência. O Pronasci estabelece 94 medidas, entre ações estruturais e programas locais, envolvendo a União, os Estados, os Municípios e a própria comunidade. O problema da criminalidade, nos termos da Lei de 2007, passou a ser visto como uma responsabilidade de âmbito Federal, Estadual, Distrital, Municipal e da sociedade, de forma integrada, e não mais, por exemplo, Federal ou Estadual, isoladamente. Quando analisadas as modificações propostas pelo Programa, salta aos olhos a nova visão de uma democracia participativa, com a utilização da conjunção aditiva "e" ao invés da conjunção alternativa "ou", quando se arrolam os atores de políticas públicas.

A título ilustrativo, uma das ações estruturais previstas é a implantação de Territórios de Paz, com foco no projeto Mulheres da Paz, destinado à capacitação de mulheres socialmente atuantes. Esse programa tem o objetivo de promover a emancipação das mulheres, a prevenção e o enfrentamento da violência contra as mulheres, isto é, um verdadeiro projeto de inclusão social do país.

O público-alvo das ações que integram o Pronasci é dividido em quatro focos: foco etário (população juvenil de 15 a 24 anos), foco social (jovens e adolescentes egressos do sistema prisional ou em situação de moradores de rua, famílias expostas à violência urbana, 
vítimas de criminalidade e mulheres em situação de violência), foco territorial (regiões metropolitanas e aglomerados urbanos que apresentem altos índices de homicídios e de crimes violentos) e foco repressivo relacionado ao combate de crime organizado. Dentre as diretrizes do Programa, apresentadas no art. 3. ${ }^{\circ}$ da Lei 11.530/2007, ${ }^{31}$ destaca-se o inciso VIII, que prevê a participação e a inclusão em programas capazes de responder, de modo consistente e permanente, as demandas das vítimas de criminalidade, por intermédio de apoio psicológico, jurídico e social, não desprezando as demais diretrizes, que, direta ou indiretamente, refletem nas políticas públicas de segurança e proteção das vítimas de delito.

As disposições que prestigiam a vítima, se dissociadas da positivação de planos, programas, projetos e ações de Estado, tendem a ensejar preceitos jurídicos carentes de efetividade. A ação estatal que ampara o funcionamento do sistema de justiça criminal deve, pois, necessariamente atuar de modo articulado com as políticas públicas que abrangem o programa de segurança pública do Estado como um todo. Essa necessária articulação se dá, pois, com a assunção dos temas de políticas públicas à problematização dos temas jurídicos dirigidos à proteção da vítima.

\subsection{APROXIMAÇÃO DAS POLÍTICAS PÚBLICAS: ATORES E PLANOS DE REALIZAÇÃO}

A definição jurídica do termo políticas públicas não encontra consenso na doutrina especializada. Dallari Bucci vê as políticas públicas como "metas coletivas conscientes", como programas de ações governamentais resultantes de um processo ou como conjunto de processos juridicamente regulados, por exemplo, processo administrativo, processo eleitoral, processo judicial, processo de planejamento. Para essa vertente, as políticas públicas propõem-se a articular os recursos disponíveis do Estado e das atividades privadas, para a promoção de objetivos socialmente relevantes e politicamente determinados. ${ }^{32}$ Em contrapartida, Comparato ${ }^{33}$ define as políticas públicas como um conjunto de normas e atos oriundos de um sistema legislativo, direcionados a uma finalidade pública determinada e unificada.

A despeito de haver diversas definições e abordagens de política pública, para o presente estudo, não é de grande valia destacá-las e diferenciá-las individualmente. Para os fins do presente estudo, basta a compreensão de que as políticas públicas são diretrizes elaboradas para enfrentar um problema público - "diferença entre o que é e aquilo que se gostaria que fosse a realidade pública". ${ }^{34}$ Secchi destaca dois elementos como fundamentais para a política pública: "intencionalidade pública e resposta a um problema público; em outras palavras, a razão para o estabelecimento de uma política pública é o tratamento ou a resolução de um problema entendido como coletivamente relevante". ${ }^{35}$

O processo de elaboração de políticas públicas recebe o nome de ciclo de políticas públicas e compreende sete fases principais: identificação do problema, formação da agenda, formulação de alternativas, tomada de decisão, implementação, avaliação e extinção. ${ }^{36}$ Essas 
fases não se apresentam sempre na mesma sequência, mas sim de forma heterogênea, a fim de se adequar a cada caso concreto, demonstrando que o processo de políticas públicas é incerto e os limites entre as fases não são claros. Entretanto, o ciclo de políticas públicas se destaca devido à sua funcionalidade para organizar as ideias e diminuir a complexidade da sua implementação.

Atores, no âmbito das políticas públicas, são os indivíduos, as organizações ou os grupos que exercem um papel na arena pública, dentre os quais se destacam os capazes de influenciar, direta ou indiretamente, o conteúdo e os resultados da política pública. A configuração de atores se apresenta em função de cada arena política, a depender de alguns fatores: relação dos resultados da política pública com as atividades do ator; probabilidade de efeitos positivos ou negativos sobre suas atividades; presença territorial do ator na área de aplicação; acessibilidade aos processos decisórios e de implementação das políticas públicas. ${ }^{37}$

A respeito da titularidade da promoção dos direitos assegurados às vítimas, a noção de políticas públicas não se coaduna com a atuação isolada de um ator, pois, até nas políticas públicas em que a norma prevê um protagonista específico, há a influência de diversos atores ao longo de um ciclo político. Na esfera específica das políticas públicas atinentes à vítima, há tanto atores governamentais quanto não governamentais; isso demonstra, $a$ fortiori, não ser um tema protagonizado exclusivamente pelo sistema de justiça criminal. Desse modo, é possível perceber, à primeira vista, a necessidade da existência de um arranjo institucional de segurança pública e uma atuação integrada, sem partilhas definidas de responsabilidades.

Os atores governamentais são aqueles que atuam em nome do Estado. Ultrapassando a clássica conformação tripartite dos Poderes Executivo, Legislativo, Judiciário, organizações como o Ministério Público, a Defensoria Pública, a Organização dos Advogados do Brasil $(\mathrm{OAB})$, dentre outras, fazem o papel de atores governamentais e se destacam quando da elaboração, da execução e da avaliação de políticas públicas de proteção às vítimas de crime. Já os atores não governamentais são os indivíduos, os grupos e as associações que representam a sociedade civil, por exemplo, as organizações não governamentais (ONG's), os conselhos estaduais e municipais, os grupos comunitários e os cidadãos que atuam em prol da pacificação do seio comunitário. Pode-se afirmar que, com base na atuação dos atores governamentais e dos não governamentais, o ideal é uma atuação integrada, uma vez que assegurar os direitos das vítimas não é tema exclusivamente normativo ou jurídico, e a atuação isolada de atores governamentais revela-se fadada ao fracasso.

No tocante aos planos de realização, sob uma perspectiva focada na satisfação do interesse compensatório da vítima, evidencia-se uma ideia de solidariedade social, ainda que subsidiária, nas hipóteses em que o acusado não dispõe de meios suficientes para reparar a vítima. Pretende-se assegurar uma tempestiva e efetiva tutela da vítima, por intermédio de um esforço coletivo, com o fim de evitar os riscos dos meios reparatórios tradicionais. 
Essa necessidade de implementação de instrumentos de reparação pública é recomendada por Organismos Internacionais, ${ }^{38}$ dentre os quais se destacam as previsões do Estatuto de Roma, integrado ao ordenamento jurídico mediante o Decreto n. 4.388, de 25 de setembro de $2002 .{ }^{39}$ O Estatuto, em seu artigo 75 , reconhece o papel fundamental das vítimas e estabelece a reparação em favor delas, com natureza de restituição, indenização ou reabilitação, com o fim de prestar-lhes amparo econômico. Já no artigo 79, estabelece a criação de um Fundo a favor das vítimas de crimes da competência do Tribunal, bem como das respectivas famílias, e o inciso 2 desse artigo dispõe que: "O Tribunal poderá ordenar que o produto das multas e quaisquer outros bens declarados perdidos revertam para o Fundo." ${ }^{40} \mathrm{~A}$ iniciativa de criação de Fundo para amparar as vítimas de crime - a exemplo do previsto pelo Estatuto de Roma para os crimes de competência do Tribunal Penal Internacional - deveria ser reproduzida internamente, de modo a beneficiar todas as vítimas de crime.

A Lei Maria da Penha traz outras ações a serem implementadas no âmbito das políticas públicas de proteção à vítima, especialmente violência doméstica contra mulher. O capítulo I da Lei 11.340/06, ${ }^{41}$ intitulado "Das medidas integradas de prevenção", além de determinar que a política pública deva ser realizada por meio de um conjunto articulado de ações da União, dos Estados, do Distrito Federal e dos Municípios e de ações não governamentais, estabelece algumas diretrizes, as quais, dada a sua relevância, merecem expressa citação (destaques nossos):

Art. $8^{\circ}[\ldots]$

I - a integração operacional do Poder Judiciário, do Ministério Público e da Defensoria Pública com as áreas de segurança pública, assistência social, saúde, educação, trabalho e habitação;

II - a promoção de estudos e pesquisas, estatísticas e outras informações relevantes, com a perspectiva de gênero e de raça ou etnia, concernentes às causas, às consequências e à frequência da violência doméstica e familiar contra a mulher, para a sistematização de dados, a serem unificados nacionalmente, e a avaliação periódica dos resultados das medidas adotadas;

III - o respeito, nos meios de comunicação social, dos valores éticos e sociais da pessoa e da familia, de forma a coibir os papéis estereotipados que legitimem ou exacerbem a violência doméstica e familiar, de acordo com o estabelecido no inciso III do art. 1o, no o inciso IV do art. 3o e no inciso IV do art. 221 da Constituição Federal;

IV - a implementação de atendimento policial especializado para as mulheres, em particular nas Delegacias de Atendimento à Mulher;

$\mathrm{V}$ - a promoção e a realização de campanhas educativas de prevenção da violência doméstica e familiar contra a mulher, voltadas ao público escolar e à sociedade em geral, e a difusão desta Lei e dos instrumentos de proteção aos direitos humanos das mulheres;

VI - a celebração de convênios, protocolos, ajustes, termos ou outros instrumentos de promoção de parceria entre órgãos governamentais ou entre estes e entidades não-governamentais, tendo por objetivo a implementação de programas de erradicação da violência doméstica e familiar contra a mulher; 
VII - a capacitação permanente das Polícias Civil e Militar, da Guarda Municipal, do Corpo de Bombeiros e dos profissionais pertencentes aos órgãos e às áreas enunciados no inciso I quanto às questões de gênero e de raça ou etnia; VIII - a promoção de programas educacionais que disseminem valores éticos de irrestrito respeito à dignidade da pessoa humana com a perspectiva de gênero e de raça ou etnia;

IX - o destaque, nos currículos escolares de todos os níveis de ensino, para os conteúdos relativos aos direitos humanos, à equidade de gênero e de raça ou etnia e ao problema da violência doméstica e familiar contra a mulher. ${ }^{42}$

A Lei 11.340/2006 ${ }^{43}$ é bom um exemplo de integração entre a atuação do sistema de justiça criminal e as ações de Estado para intervenção, de modo mais amplo e com respeito à complexidade do fenômeno da violência, no conflito ensejado pela prática criminosa. Nesse sentido, a Lei trouxe algumas inovações, no plano das políticas públicas, a serem implementadas não somente no âmbito de violência doméstica contra a mulher, mas a todas as espécies de crime. Dentre as inovações, tem-se a integração operacional, a ser mencionada no próximo capítulo; a promoção de estudos e pesquisas, visando à sistematização de dados, com a devida avaliação periódica dos resultados das medidas adotadas; a implementação de atendimento policial especializado e a celebração de instrumentos de promoção de parceria entre órgãos governamentais ou entre estes e entidades não governamentais. Outra iniciativa implementada por essa Lei foram as chamadas medidas protetivas de urgência (arts. 18-24 e ss.), com o fim de proteger efetivamente a mulher vítima de violência doméstica. Esse instituto teve como inspiração as restraining orders do direito inglês, orientadas por dois fundamentos: prevenção e proteção. ${ }^{44}$ Essas medidas anteciparam a reforma das medidas cautelares, operada no Código de Processo Penal apenas no ano de 2011 por meio da Lei 12.403, uma vez que conferiram uma maior ousadia ao legislador no uso do poder cautelar do juiz e com vistas à superação de um modelo bipolar, isto é, ora de imposição da prisão, ora de observância da liberdade do acusado de modo desvinculado ao processo-crime a que responde.

Ressalte-se, entretanto, que a ação de implementação das medidas protetivas tem como atores não só o juiz, que decidirá no caso concreto, mas também o Ministério Público e os agentes de segurança pública, no sentido de facilitar a assistência da vítima e informá-la da existência do instituto, proporcionando a sua efetivação.

A Lei Maria da Penha também trouxe atribuições específicas ao Ministério Público como ator de políticas públicas, conforme os artigos 25 e 26. Atribui-se a ele, por exemplo, fiscalizar os estabelecimentos públicos e particulares de atendimento à mulher, além de formular um cadastro com os casos de violência doméstica e familiar contra a mulher, com o objetivo de acompanhar as ocorrências e facilitar futuras atuações. Essa assunção de competência pelo Ministério Público é ilustrativa da adoção de uma abordagem cooperativa entre os Poderes e as funções do Estado. Para além da clássica divisão entre ações do Executivo, do Legislativo e do Judiciário, a Lei privilegia ações de Estado, que podem ser conduzidas, 
por certo, observada a competência legalmente estabelecida, por todos os atores estatais. A ação governamental, que traduz o desenho das políticas públicas vai muito além do desenho de competências e atribuições do Poder Executivo nos seus diversos âmbitos federativos.

No Título V, denominado "Da equipe de atendimento multidisciplinar", a Lei $11.340 / 06^{45}$ previu a criação de Juizados Especializados com uma equipe de atendimento multidisciplinar, com competência para fornecer subsídio aos demais atores e para desenvolver trabalhos de orientação, encaminhamento, prevenção e outras medidas, voltados para a ofendida. A menção à nomenclatura "Juizado" não foi gratuita. Longe de se aproximar da atuação do Judiciário para os crimes de menor potencial ofensivo - de modo específico, os Juizados Especiais Criminais mencionados no art. 98 da Constituição da República -, a adoção da expressão "Juizado" justifica-se na extrapolação do exercício de uma competência que não se dá apenas no âmbito estritamente criminal. É dizer: a Lei 11.340/2006 ${ }^{46}$ fixa um estatuto de viés substancialmente protetivo. Para tanto, tem-se no Juizado de Violência doméstica e familiar contra a mulher uma série de medidas que vão muito além da resposta tradicional ao particular a que se impute a prática de crime. Em rigor, assumem maior relevância as ações de Estado para erradicação da violência, prevenção de novas ações violentas e, sobretudo, medidas de acolhimento da vítima, ainda que em paralelo e sem prejuízo da resposta penal.

Já a Lei 11.530/2007, ${ }^{47}$ que instituiu o já mencionado Pronasci, fixa um verdadeiro marco político-criminal. Estabeleceu, de modo minudenciado, o arcabouço normativo para políticas sociais e ações de proteção às vítimas. São exemplos desse detalhamento o Projeto de Proteção de Jovens em Território Vulnerável, destinado à formação e à inclusão social de jovens e adolescentes expostos à violência doméstica ou urbana; o Projeto Mulheres de Paz, destinado à capacitação de mulheres socialmente atuantes nas áreas geográficas abrangidas pelo Pronasci; e o Projeto Bolsa-Formação, destinado à qualificação profissional dos integrantes das Carreiras de segurança pública, polícias militar e civil e outros, com o objetivo de valorizar esses profissionais e consequentemente beneficiar a sociedade brasileira. As ações e os projetos de implementação integrantes do Pronasci têm como principal ator a sociedade civil, cada vez mais agente e não apenas destinatária das leis. Exemplo da importância fornecida à sociedade civil pelo Pronasci são os projetos de inclusão e capacitação para jovens e mulheres socialmente atuantes, como agentes comunitários de prevenção e enfrentamento à violência.

Bastos $^{48}$ afirma que a pressão da sociedade civil organizada é o instrumento mais adequado para implementação de políticas públicas. A fixação e a fiscalização das políticas públicas devem ser analisadas sob a luz da soberania popular e não sob o viés da Separação de Poderes. Dito de outra forma, cabe à sociedade civil, diretamente interessada, fiscalizar a atuação dos demais atores, pressionando-os e apoiando-os, com o fim de implementar as políticas públicas. 


\subsection{ARRANJO INSTITUCIONALEUMESTREITODIÁLOGO INTERORGANIZACIONAL}

Diogo Coutinho ${ }^{49}$ escreve a respeito das interações existentes entre o direito e as políticas públicas e tece importantes distinções entre as expressões "direito das políticas públicas" e "direito nas políticas públicas", oportunidade em que aponta alguns papéis do direito nas políticas públicas. Nessa pesquisa, o autor aponta a carência do estudo das políticas públicas no âmbito do ensino jurídico e a distância acadêmica entre o Direito e o campo das políticas públicas. Embora os juristas sejam diariamente chamados a opinar e a decidir sobre questões relacionadas à política pública, muitos não estão preparados para esse diálogo, uma vez que lhes foram negligenciados, na academia, a problematização e o debate como método de estudo, apegando-se a referenciais teóricos e ensinamentos doutrinários. Dantas chega a afirmar que: "o curso jurídico é, sem exagero, um curso de institutos jurídicos, apresentados sob a forma expositiva de tratado teórico-prático". ${ }^{50}$

O fato de, academicamente, a discussão sobre os efeitos de leis e de políticas públicas ser ignorada faz com que a maioria dos juristas brasileiros não saibam distinguir os papéis no cenário das políticas públicas e consequentemente ficam deficientes no papel de formular e propor soluções ou ajustes capazes de executar e aperfeiçoar políticas públicas. Diogo Coutinho chega a supor que a falta de consciência desse papel profissional tende a aumentar o risco de que haja maior opacidade na compreensão do problema; menor participação dos atores relevantes e pouca mobilização deles para o desenvolvimento das políticas públicas. ${ }^{51}$

Essa carência do debate das políticas públicas se intensifica nas ações em prol das vítimas no processo penal. A proteção da vítima, não raro, deixa de ser mencionada na maioria dos programas de ensino jurídico brasileiro. Normalmente, a atenção dos estudiosos do direito penal é voltada à pessoa do acusado e às penas, em especial, as privativas de liberdade, ficando a vítima sem a atenção devida.

Há uma visão fragmentária, que ainda permeia as políticas públicas, defendida por juristas administrativistas, para os quais as políticas públicas são percebidas, em regra, "como uma sucessão de atos administrativos e não como um continuum articulado, dinâmico e estruturado em torno de fins previamente articulados a meios". ${ }^{52}$ As políticas públicas devem ser visualizadas como planos de ação prospectivos, em permanente processo de implementação e avaliação, não se confundindo com as categorias jurídicas dos atos administrativos.

Para que os agentes públicos possam elaborar e executar as políticas públicas, é preciso de um certo grau de discricionariedade, de uma margem de liberdade e de adaptação que vai além da dicotomia de atos vinculados ou atos discricionários. A questão não deve ser "pode ou não pode", mas sim "como se pode" e "quais as estratégias necessárias". Vale ressaltar que raramente o legislador minudencia os objetivos da política pública, o que dá lugar a caminhos alternativos para alcançá-los, uma vez que as políticas públicas estão a todo tempo em processo de adaptação, de ajustes e de avaliações. ${ }^{53}$ Isso demonstra a necessidade de flexibilizar o arcabouço jurídico para a melhor atuação dos administradores e gestores públicos. 
No caso dos direitos assegurados à vítima no processo penal, a elaboração, a execução e a avaliação de políticas públicas, em regra, ainda é analisada sob o viés de qual Poder ou ator público tem predominância ou exclusividade para atuar. Muito se discute sobre qual Poder teria melhores condições de fiscalizar a fixação e a implementação de políticas públicas. $\bigcirc$ debate sobre a competência para a concretização dessas políticas públicas, se primordialmente o Executivo ou se isso é função exclusiva do Judiciário - por se vincular umbilicalmente ao próprio processo criminal -, não se mostra relevante ou em conformidade com o contexto apresentado. Deixar a implementação das garantias aos direitos das vítimas a cargo apenas do Executivo ou exclusivamente do sistema de justiça criminal é minimizar a importância de tais direitos. O recomendável é uma atuação conjunta dos atores, dos públicos e dos privados, não mais cabendo a repartição de atribuições que outrora vigorava.

Além disso, no que se refere especificamente às políticas públicas em prol das vítimas no processo penal, não há recorrente discussão a respeito da judicialização dos direitos e do risco da interferência dos juízes nas políticas públicas, na medida em que eles, os juízes, são inegavelmente um dos atores tanto de implementação quanto de fiscalização dessas políticas. A despeito de o sistema de justiça criminal se destacar como ator dessas políticas públicas de proteção à vítima, não há que se falar em exclusividade, mas em arranjo institucional entre todos os atores de segurança pública que estejam direta ou indiretamente ligados à vítima de delito, para abranger o Ministério Público, a Defensoria Pública, as diversas Polícias, o próprio Judiciário, as equipes multidisciplinares de acolhimento e atendimento ou outros, a depender do caso concreto.

Coutinho propõe o direito como componente de um arranjo institucional com o objetivo de partilhar responsabilidades entre os atores, "uma espécie de 'mapa' de responsabilidades e tarefas nas políticas públicas." ${ }^{54}$ Já Dallari Bucci observa as próprias políticas públicas como "arranjos institucionais complexos, expressos em estratégias ou programas de ação governamental, que resultam de processos juridicamente regulados, visando a adequar fins e meios." ${ }^{55}$ A ideia de um arranjo institucional está estritamente ligada a um diálogo interorganizacional, diálogo a ser promovido entre atores das instituições públicas e estes com os atores privados, visando a aproximá-los com o intuito de que haja um preenchimento de lacunas pela complementariedade sinérgica dos atores, ressaltando as vantagens e mitigando as deficiências de cada componente do arranjo.

\subsection{INTEGRAÇÃO OPERACIONAL QUE RECLAMA POLÍTICAS DE ESTADO}

Considerando o destaque do Estado em relação aos demais atores de políticas públicas, distinguem-se as expressões "política de governo" e "política de Estado": a primeira possui relação com um grupo político detentor de mandato eletivo, isto é, a elaboração e o estabelecimento de políticas públicas têm prazo determinado, a depender do mandato eletivo. Já a política de Estado independe de ciclos eleitorais e visa a atender a demandas não solu- 
cionáveis em mandatos, na medida em que depende de orientações e ações de longo prazo para impactar o quadro social.

As políticas públicas voltadas para a proteção da vítima no processo penal não podem ficar à mercê de jogo de interesses e a critério de grupos políticos detentores de mandato eletivo. Há de se buscar estratégias de controle de criminalidade socialmente orientado à vítima, sob um prisma tanto preventivo como reparatório, isto é, uma política criminal mais próxima do sistema penal da realidade social, destinada à estabilização social sob a perspectiva vitimológica. O nível de titularidade de conformação das políticas públicas em prol das vítimas de crime, pela análise da legislação federal na última década, tem exigido um arranjo institucional que vai além da tradicional separação dos poderes. Utilizando-se das previsões da Lei n. 11.340/2006, ${ }^{56}$ cuida-se de um conjunto articulado de ações, ao lado de uma integração operacional do Poder Judiciário, do Ministério Público e da Defensoria Pública com áreas de segurança pública, assistência social, saúde, educação, trabalho e habitação.

Essa integração operacional se refere a uma atuação mais conjunta entre os atores, em que um ator complementa a ação de outro ator, sem que haja uma repartição específica de atribuições e competências. Cada ator deve saber a importância do seu papel para a efetividade da política pública. Cita-se o importante papel da sociedade civil como ator dessas políticas públicas, em prol da concreção do direito social à segurança pública. A democracia não se restringe ao viés de status (democracia representativa), mas há de ser compreendida como uma prática política. "A democracia considerada como prática política implica um projeto de construção ética do bem comum a partir da participação cidadã". ${ }^{57}$

A efetividade e a eficácia da implementação das políticas públicas de atendimento às vítimas parte do pressuposto de que é necessário um estreito diálogo interorganizacional, com a participação ética da sociedade civil e de todos os demais atores, comunicando e cooperando entre si, com um único objetivo: efetivar ações de proteção às vítimas de delito.

\section{CONCLUSÃO}

A partir da premissa de que as vítimas de crime são aquelas pessoas que sofrem direta ou indiretamente com as consequências do delito, isto é, o sujeito passivo eventual da prática criminosa, é possível constatar a relevância de que sejam implementadas políticas públicas com o fim de protegê-las e de minimizar os processos de vitimização.

A legislação mais recente tem mostrado que, apesar de a missão principal da Justiça criminal não ser a reparação da vítima, há uma tendência despenalizadora que valoriza a reparação da vítima e evita processos de vitimização gerados pela persecução penal. Essa tendência demonstra uma orientação legislativa com viés de humanização do processo penal. As modificações legislativas, na última década, tiveram como diretrizes quatro aspectos dos direitos vitimais: direito à proteção, direito à informação, direito à participação e direito à 
solução consensual do processo. Entretanto, as leis que mais se destacam no que se refere especificamente às políticas públicas em prol das vítimas são a Lei 11.340/2006 e a Lei 11.530/2007, pois ambas estabelecem medidas e ações de segurança pública voltadas para a vítima de delito.

No que se refere às políticas públicas, é possível afirmar que são diretrizes elaboradas para enfrentar um problema público com o fim de se modificar a realidade, utilizando-se de atores governamentais e não governamentais. Esses atores não possuem atribuições rígidas ou formalmente delimitadas. Ao contrário, os atores devem interagir e se auto complementar, em prol de melhor implementar as políticas públicas.

A ausência de interações entre o direito e as políticas públicas, no âmbito acadêmico, demonstra um provável despreparo da maioria dos juristas para distinguir os diferentes papéis no cenário das políticas públicas, o que gera um risco de maior opacidade na percepção do problema, menor participação dos atores relevantes e pouca mobilização desses para o implemento das políticas públicas.

Especificamente em relação às políticas públicas de proteção à vítima no processo penal, não há que se falar em protagonismo de um ator, nem da exclusividade de atuação do sistema de justiça criminal, por mais perto que esse último esteja próximo da vítima, devido à persecução penal. A conformação legislativa mais recente, com destaque para aquela positivada na última década, tem por pressuposto para a sua efetividade a observância de um estreito diálogo dos atores dentro das organizações e entre elas, em uma atuação conjunta e integrada.

Assim, conclui-se que a inclinação legislativa na última década apresenta uma conformação de políticas públicas em prol das vítimas no processo criminal voltada para a atuação conjunta dos atores de políticas públicas no modelo de arranjo institucional. No entanto, essa conformação pressupõe políticas de Estado, que independem dos ciclos eleitorais e são implementadas a longo prazo, com ações contínuas. Percebe-se a necessidade de aplicação empírica desse modelo de arranjo institucional, com uma mudança de postura dos atores de políticas públicas, para evitar que as normas já existentes careçam de efetividade e eficácia.

\section{REFERENNCIAS}

BARROS, Flaviane de Magalhães. A participação da vítima no Processo Penal. Rio de Janeiro: Lumen Juris, 2008.

BASTOS, Elísio Augusto Velloso. A importância da Cidadania na definição e na implementação de políticas públicas. In: MORAES, Alexandre de; KIM, Richard Pae. Cidadania: o novo conceito jurídico e a sua relação com os direitos fundamentais individuais e coletivos. São Paulo: Atlas, 2013. 
BERISTAIN, Antonio. Nova criminologia à luz do direito penal e da vitimologia. Tradução de Cândido Furtado Maia Neto. Brasília: Universidade de Brasília, 2000.

BLANCAFORT, Albert Calsamiglia. Sobre la dogmática jurídica presupuestos y funciones del saber jurídico. Anales de la Cátedra Francisco Suárez, n. 22, p. 235-276, 1982.

BRASIL. Decreto $n^{0}$ 4.388, de 25 de setembro de 2002. Promulga o Estatuto de Roma do Tribunal Penal Internacional. Presidência da República, Brasília, DF. Disponível em: <http://www.planalto.gov.br/ccivil_03/decreto/2002/D4388.htm>. Acesso em: 27 ago. 2016.

. Lei n ${ }^{0}$ 9.099, de 26 de setembro de 1995. Dispõe sobre os Juizados Especiais Cíveis e Criminais e dá outra providências. Presidência da República, Brasília, DF. Disponível em: <http://www.planalto.gov.br/ccivil_03/leis/L9099.htm>. Acesso em: 12 set. 2016.

. Lei $n^{0} 11.340$, de 7 de agosto de 2006. Cria mecanismos para coibir a violência doméstica e familiar contra a mulher, nos termos do $\$ 8^{\circ}$ do art. 226 da Constituição Federal, da Convenção sobre a Eliminação de Todas as Formas de Discriminação contra as Mulheres e da Convenção Interamericana para Prevenir, Punir e Erradicar a Violência contra a Mulher; dispõe sobre a criação dos Juizados de Violência Doméstica e Familiar contra a Mulher; altera o Código de Processo Penal, o Código Penal e a Lei de Execução Penal; e dá outras providências. Presidência da República, Brasília, DF. Disponível em: < http://www. planalto.gov.br/ccivil_03/_ato2004-2006/2006/lei/111340.htm>. Acesso em: 27 jun. 2016.

. Lei n ${ }^{\mathrm{O}} 11.530$, de 24 de outubro de 2007. Institui o Programa Nacional de Segurança Pública com Cidadania - PRONASCI e dá outras providências. Presidência da República, Brasília, DF. Disponível em: <http://www.planalto.gov.br/ccivil_03/_ato2007-2010/2007/ Lei/L11530.htm>. Acesso em: 27 jun. 2016.

. Lei n ${ }^{0} 11.690$, de 9 de junho de 2008. Altera dispositivos do Decreto-Lei n. 3.689, de 3 de outubro de 1941 - Código de Processo Penal, relativos à prova, e dá outras providências. Presidência da República, Brasília, DF. Disponível em: <http:/www.planalto.gov.br/ccivil_03/_ato2007-2010/2008/lei/111690.htm>. Acesso em: 26 jun. 2016.

. Lei $\mathrm{n}^{\mathrm{o}} 11.719$, de 20 de junho de 2009. Altera dispositivos do Decreto-Lei n. 3.689, de 3 de outubro de 1941 - Código de Processo Penal, relativos à suspensão do processo, emendatio libelli, mutattio libelli e aos procedimentos. Presidência da República, Brasília, DF. Disponível em: <http:/www.planalto.gov.br/ccivil_03/_Ato2007-2010/2008/Lei/L11719. htm $>$. Acesso em: 27 jun. 2016.

. Lei $\mathrm{n}^{\mathrm{O}}$ 12.015, de 7 de agosto de 2009. Altera o Título VI da Parte Especial do Decreto-Lei n. 2.848, de 7 de dezembro de 1940 - Código Penal, e o art. 1o da Lei n. 8.072, de 25 de julho de 1990, que dispõe sobre os crimes hediondos, nos termos do inciso XLIII do art. 5o da Constituição Federal e revoga a Lei n. 2.252, de 1o de julho de 1954, que trata de corrupção de menores. Presidência da República, Brasília, DF. Disponível em: < http://www. planalto.gov.br/ccivil_03/_ato2007-2010/2009/lei/112015.htm>. Acesso em: 7 ago. 2016. 
. Lei $\mathrm{n}^{\circ} 12.415$, de 9 de junho de 2011. Acrescenta parágrafo único ao art. 130 da Lei n. 8.069, de 13 de julho de 1990 (ECA), para determinar que alimentos provisórios sejam fixados cautelarmente em favor da criança ou dos adolescente cujo agressor seja afastado da moradia comum por determinação judicial. Presidência da República, Brasília, DF. Disponível em: < http://www.planalto.gov.br/ccivil_03/_Ato2011-2014/2011/Lei/L12415. htm>. Acesso em: 27 jun. 2016.

. Lei $\mathrm{n}^{\mathrm{o}} 12.461$, de 26 de julho de 2011. Altera a Lei n. 10.741, de 1o de outubro de 2003, para estabelecer a notificação compulsória dos atos de violência praticados contra idoso atendido em serviço de saúde. Presidência da República, Brasília, DF. Disponível em: <http://www.planalto.gov.br/ccivil_03/_Ato2011-2014/2011/Lei/L12461.htm>. Acesso em: 27 jun. 2016.

. Lei $\mathrm{n}^{\mathrm{O}} 12.483$, de 8 de setembro de 2011. Acresce o art. 19-A à Lei n. 9.807, de 13 de julho de 1999, que estabelece normas para a organização e a manutenção de programas especiais de proteção a vítimas e testemunhas ameaçadas, institui o Programa Federal de Assistência a Vítimas e a Testemunhas Ameaçadas e dispõe sobre a proteção de acusados ou condenados que tenham voluntariamente prestado efetiva colaboração à investigação policial e ao processo criminal. Presidência da República, Brasília, DF. Disponível em: <http://www. planalto.gov.br/ccivil_03/_Ato2011-2014/2011/Lei/L12483.htm>. Acesso em: 27 jun. 2016.

. Lei $\mathrm{n}^{\mathrm{o}} 12.845$, de $1^{\circ}$ de agosto de 2013. Dispõe sobre o atendimento obrigatório e integral de pessoas em situação de violência sexual. Presidência da República, Brasília, DF. Disponível em: < http://www.planalto.gov.br/ccivil_03/_ato2011-2014/2013/lei/112845. htm >. Acesso em: 27 jun. 2016.

BUCCI, Maria Paula Dallari. O conceito de política pública em direito. In: BUCCI, Maria Paula Dallari. Políticas públicas: reflexões sobre o conceito jurídico. São Paulo: Saraiva, 2006.

BUCCI, Maria Paula Dallari. Direito administrativo e políticas públicas. São Paulo: Saraiva, 2002.

BUCCI, Maria de Paula Dallari. Notas para uma metodologia jurídica de análise de políticas públicas. In: FORTINI, Cristina; ESTEVES, Júlio César dos Santos; DIAS, Maria Tereza Fonseca. Políticas públicas: possibilidades e limites. Belo Horizonte: Fórum, 2008.

CÂMARA, Guilherme Costa. Programa de política criminal: orientado para a vítima de crime. São Paulo: Revista dos Tribunais, 2008.

COMPARATO, Fábio Konder. Ensaio sobre o juízo de constitucionalidade de políticas públicas. São Paulo: Revista dos Tribunais, 1997.

COUTINHO, Diogo R. O direito nas políticas públicas. In: MARQUES, Eduardo; FARIA, Carlos Aurélio Pimenta de. Política Pública como campo disciplinar. São Paulo: Unesp; Rio de Janeiro: Fiocruz, 2013. 
FERNANDES, Antonio Scarance. O papel da vítima no processo criminal. São Paulo: Malheiros, 1995.

FERRAJOLI, Luigi. Direito e razão: teoria do garantismo penal. Tradução Ana Paula Zomer, Fauzi Hassan Choukr, Juarez Tavares e Luiz Flávio Gomes. São Paulo: Revista dos Tribunais, 2002.

GOMES, Luiz Flávio; MOLINA, Antonio García-Pablos de. Criminologia. 3. ed. Tradução Luiz Flávio Gomes. São Paulo: Revista dos Tribunais, 2000.

LIMA, Renato Brasileiro de. Manual de processo penal: volume único. Salvador: JusPodivm, 2016.

MAIA NETO, Cândido Furtado. Direitos humanos das vítimas de crimes: filosofia penal e teoria crítica à luz das reformas processuais penais. Curitiba: Juruá, 2014.

MAZZUTTI, Vanessa de Biossio. Vitimologia e direitos humanos: o processo penal sob a perspectiva da vítima. Curitiba: Juruá, 2012.

NACIF, Eleonora Rangel. A mídia e o processo penal. Observatório da Imprensa, v. 13, n. 622, 28 dez. 2010. Disponível em <http://observatoriodaimprensa.com.br/>. Acesso em: 20 dez. 2016.

OLIVEIRA, Ana Sofia Schmidt de. A vítima e o direito penal. São Paulo: Revista dos Tribunais, 1999.

ORGANIZAÇÃO DAS NAÇÕES UNIDAS. Assembleia Geral. Resolução 40/34, de 29.11.1985. Disponível em: <http:/www.direitoshumanos.usp.br/index.php/Direitos-Humanos-na-Administração-da-Justiça.-Proteção-dos-Prisioneiros-e-Detidos.-Proteção-contra-a-Tortura-Maus-tratos-e-Desaparecimento/declaracao-dos-principios-basicos-de-justica-relativos-as-vitimas-da-criminalidade-e-de-abuso-de-poder.html>. Acesso em: 9 jul. 2016.

RODRIGUES, Roger de Melo. A tutela da vítima no processo penal brasileiro. Curitiba: Juruá, 2014.

SECCHI, Leonardo. Políticas públicas: conceitos, esquemas de análise, casos práticos. 2. ed. São Paulo: Cengage Learning, 2013.

SUXBERGER, Antonio Henrique Graciano. Ministério Público e política criminal: uma segurança pública compromissada com os direitos humanos. Curitiba: Juruá, 2010.

SUXBERGER, Antonio Henrique Graciano. O Sistema Inglês. In: ÁVILA, Thiago André Pierobom de, et al. Modelos Europeus de enfrentamento à violência de gênero: experiências e representações sociais. Brasília: ESMPU, 2014.

. Os riscos de violência institucional na violência de gênero: uma necessária contribuição da teoria crítica dos direitos humanos. In: BARBOSA, Theresa K. de F. G. A mulher e a justiça: a violência doméstica sob a ótica dos direitos humanos. Brasília: Amagis, 2016. p. 199-218. 
1 COUTINHO, Diogo R. O direito nas políticas públicas. In: MARQUES, Eduardo; FARIA, Carlos Aurélio Pimenta de. Política Pública como campo disciplinar. São Paulo: Unesp; Rio de Janeiro: Fiocruz, 2013. p. 183.

2 COUTINHO, Diogo R. O direito nas políticas públicas. In: MARQUES, Eduardo; FARIA, Carlos Aurélio Pimenta de. Política Pública como campo disciplinar. São Paulo: Unesp; Rio de Janeiro: Fiocruz, 2013. p. 185.

3 BLANCAFORT, Albert Calsamiglia. Sobre la dogmática jurídica presupuestos y funciones del saber jurídico. Anales de la Cátedra Francisco Suárez, n. 22, p. 235-276, 1982.

4 GOMES, Luiz Flávio; MOLINA, Antonio García-Pablos de. Criminologia. 3. ed. Tradução Luiz Flávio Gomes. São Paulo: Revista dos Tribunais, 2000. p. 73.

5 ORGANIZAÇÃO DAS NAÇÕES UNIDAS. Assembleia Geral. Resolução 40/34, de 29.11.1985. Disponível em: < http://www.direitoshumanos.usp.br/index.php/Direitos-Humanos-na-Administração-da-Justiça.-Proteção-dos-Prisioneiros-e-Detidos.-Proteção-contra-a-Tortura-Maus-tratos-e-Desaparecimento/declaracao-dos-principios-basicos-de-justica-relativos-as-vitimas-da-criminalidade-e-de-abuso-de-poder.html >. Acesso em: 9 jul. 2016.

6 ORGANIZAÇÃO DAS NAÇÕES UNIDAS. Assembleia Geral. Resolução 40/34, de 29.11.1985. Disponível em: <http://www.direitoshumanos.usp.br/index.php/Direitos-Humanos-na-Administração-da-Justiça.-Proteção-dos-Prisioneiros-e-Detidos.-Proteção-contra-a-Tortura-Maus-tratos-e-Desaparecimento/declaracao-dos-principios-basicos-de-justica-relativos-as-vitimas-da-criminalidade-e-de-abuso-de-poder.html>. Acesso em: 9 jul. 2016.

7 MAIA NETO, Cândido Furtado. Direitos humanos das vítimas de crimes: filosofia penal e teoria crítica à luz das reformas processuais penais. Curitiba: Juruá, 2014. p. 362-363.

8 FERRAJOLI, Luigi. Direito e razão: teoria do garantismo penal. Tradução Ana Paula Zomer, Fauzi Hassan Choukr, Juarez Tavares e Luiz Flávio Gomes. São Paulo: Revista dos Tribunais, 2002. p. 269.

9 BRASIL. Lei no 9.099, de 26 de setembro de 1995. Dispõe sobre os Juizados Especiais Cíveis e Criminais e dá outra providências. Presidência da República, Brasília, DF. Disponível em: <http://www.planalto.gov.br/ ccivil_03/leis/L9099.htm>. Acesso em: 12 set. 2016.

10 BARROS, Flaviane de Magalhães. A participação da vítima no Processo Penal. Rio de Janeiro: Lumen Juris, 2008. p. 70.

11 FERNANDES, Antonio Scarance. O papel da vítima no processo criminal. São Paulo: Malheiros, 1995. p. 38.

12 RODRIGUES, Roger de Melo. A tutela da vítima no processo penal brasileiro. Curitiba: Juruá, 2014. p. 69.

13 Lei n $^{\circ}$ 11.690, de 9 de junho de 2008. Altera dispositivos do Decreto-Lei n. 3.689, de 3 de outubro de 1941 - Código de Processo Penal, relativos à prova, e dá outras providências. Presidência da República, Brasília, DF. Disponível em: <http://www.planalto.gov.br/ccivil_03/_ato2007-2010/2008/lei/111690.htm>. Acesso em: 26 jun. 2016.

14 FERRAJOLI, Luigi. Direito e razão: teoria do garantismo penal. Tradução Ana Paula Zomer, Fauzi Hassan Choukr, Juarez Tavares e Luiz Flávio Gomes. São Paulo: Revista dos Tribunais, 2002. p. 567.

15 BRASIL. Lei $n^{\circ}$ 12.015, de 7 de agosto de 2009. Altera o Título VI da Parte Especial do Decreto-Lei n. 2.848, de 7 de dezembro de 1940 - Código Penal, e o art. 1o da Lei n. 8.072, de 25 de julho de 1990, que dispóe sobre os crimes hediondos, nos termos do inciso XLIII do art. 5o da Constituição Federal e revoga a Lei n. 2.252, de 1 o de julho de 1954, que trata de corrupção de menores. Presidência da República, Brasília, DF. Disponível em: <http://www.planalto.gov.br/ccivil_03/_ato2007-2010/2009/lei/112015.htm>. Acesso em: 7 ago. 2016.

16 NACIF, Eleonora Rangel. A mídia e o processo penal. Observatório da Imprensa, v. 13, n. 622, 28 dez. 2010. Disponível em <http://observatoriodaimprensa.com.br/>. Acesso em: 20 dez. 2016.

17 BRASIL.Lei n ${ }^{\circ}$ 11.690, de 9 de junho de 2008. Altera dispositivos do Decreto-Lei n. 3.689, de 3 de outubro de 1941 - Código de Processo Penal, relativos à prova, e dá outras providências. Presidência da República, Brasília, DF. Disponível em: <http://www.planalto.gov.br/ccivil_03/_ato2007-2010/2008/lei/111690.htm>. Acesso em: 26 jun. 2016.

18 BRASIL. Lei no 11.719, de 20 de junho de 2009. Altera dispositivos do Decreto-Lei n. 3.689, de 3 de outubro de 1941 - Código de Processo Penal, relativos à suspensão do processo, emendatio libelli, mutattio libelli e aos procedimentos. Presidência da República, Brasília, DF. Disponível em: <http://www.planalto.gov.br/ ccivil_03/_Ato2007-2010/2008/Lei/L11719.htm>. Acesso em: 27 jun. 2016.

19 LIMĀ, Renato Brasileiro de. Manual de processo penal: volume único. Salvador: JusPodivm, 2016. p. 307. 
20 Ibid., p. 308.

21 BRASIL. Lei no 12.415, de 9 de junho de 2011. Acrescenta parágrafo único ao art. 130 da Lei n. 8.069, de 13 de julho de 1990 (ECA), para determinar que alimentos provisórios sejam fixados cautelarmente em favor da criança ou dos adolescente cujo agressor seja afastado da moradia comum por determinação judicial. Presidência da República, Brasília, DF. Disponível em: <http://www.planalto.gov.br/ccivil_03/_Ato2011-2014/2011/Lei/ L12415.htm>. Acesso em: 27 jun. 2016.

22 BRASIL. Lei $\mathrm{n}^{\mathrm{O}}$ 12.461, de 26 de julho de 2011. Altera a Lei n. 10.741, de 1o de outubro de 2003, para estabelecer a notificação compulsória dos atos de violência praticados contra idoso atendido em serviço de saúde. Presidência da República, Brasília, DF. Disponível em: <http://www.planalto.gov.br/ccivil_03/_Ato20112014/2011/Lei/L12461.htm>. Acesso em: 27 jun. 2016.

23 BRASIL. Lei no 12.483, de 8 de setembro de 2011. Acresce o art. 19-A à Lei n. 9.807, de 13 de julho de 1999, que estabelece normas para a organização e a manutenção de programas especiais de proteção a vítimas e testemunhas ameaçadas, institui o Programa Federal de Assistência a Vítimas e a Testemunhas Ameaçadas e dispõe sobre a proteção de acusados ou condenados que tenham voluntariamente prestado efetiva colaboração à investigação policial e ao processo criminal. Presidência da República, Brasília, DF. Disponível em: <http:// www.planalto.gov.br/ccivil_03/_Ato2011-2014/2011/Lei/L12483.htm>. Acesso em: 27 jun. 2016.

24 BRASIL. Lei ${ }^{\circ} 12.845$, de $1^{\circ}$ de agosto de 2013. Dispõe sobre o atendimento obrigatório e integral de pessoas em situação de violência sexual. Presidência da República, Brasília, DF. Disponível em: <http://www. planalto.gov.br/ccivil_03/_ato2011-2014/2013/lei/112845.htm>. Acesso em: 27 jun. 2016.

25 Lei $^{\circ} 11.340$, de 7 de agosto de 2006 . Cria mecanismos para coibir a violência doméstica e familiar contra a mulher, nos termos do $\S 8^{\circ}$ do art. 226 da Constituição Federal, da Convenção sobre a Eliminação de Todas as Formas de Discriminação contra as Mulheres e da Convenção Interamericana para Prevenir, Punir e Erradicar a Violência contra a Mulher; dispõe sobre a criação dos Juizados de Violência Doméstica e Familiar contra a Mulher; altera o Código de Processo Penal, o Código Penal e a Lei de Execução Penal; e dá outras providências. Presidência da República, Brasília, DF. Disponível em: < http://www.planalto.gov.br/ccivil_03/_ato20042006/2006/lei/111340.htm>. Acesso em: 27 jun. 2016.

26 BRASIL. Lei $n^{\circ} 11.530$, de 24 de outubro de 2007. Institui o Programa Nacional de Segurança Pública com Cidadania - PRONASCI e dá outras providências. Presidência da República, Brasília, DF. Disponível em: <http://www.planalto.gov.br/ccivil_03/_ato2007-2010/2007/Lei/L11530.htm>. Acesso em: 27 jun. 2016.

27 BRASIL. Lei $\mathrm{n}^{\mathrm{o}}$ 11.340, de 7 de agosto de 2006. Cria mecanismos para coibir a violência doméstica e familiar contra a mulher, nos termos do $\S 8^{\circ}$ do art. 226 da Constituição Federal, da Convenção sobre a Eliminação de Todas as Formas de Discriminação contra as Mulheres e da Convenção Interamericana para Prevenir, Punir e Erradicar a Violência contra a Mulher; dispõe sobre a criação dos Juizados de Violência Doméstica e Familiar contra a Mulher; altera o Código de Processo Penal, o Código Penal e a Lei de Execução Penal; e dá outras providências. Presidência da República, Brasília, DF. Disponível em: <http://www.planalto.gov.br/ ccivil_03/_ato2004-2006/2006/lei/111340.htm>. Acesso em: 27 jun. 2016.

28 SUXBERGER, Antonio Henrique Graciano. Os riscos de violência institucional na violência de gênero: uma necessária contribuição da teoria crítica dos direitos humanos. In: BARBOSA, Theresa K. de F. G. A mulher e a justiça: a violência doméstica sob a ótica dos direitos humanos. Brasília: Amagis, 2016. p. 199-218. p. 207.

29 Ibid., p. 208.

30 BRASIL. Lei $n^{\circ}$ 11.530, de 24 de outubro de 2007. Institui o Programa Nacional de Segurança Pública com Cidadania - PRONASCI e dá outras providências. Presidência da República, Brasília, DF. Disponível em: <http://www.planalto.gov.br/ccivil_03/_ato2007-2010/2007/Lei/L11530.htm>. Acesso em: 27 jun. 2016.

31 BRASIL. Lei $\mathrm{n}^{\circ}$ 11.530, de 24 de outubro de 2007. Institui o Programa Nacional de Segurança Pública com Cidadania - PRONASCI e dá outras providências. Presidência da República, Brasília, DF. Disponível em: <http://www.planalto.gov.br/ccivil_03/_ato2007-2010/2007/Lei/L11530.htm>. Acesso em: 27 jun. 2016.

32 BUCCI, Maria Paula Dallari. O conceito de política pública em direito. In: BUCCI, Maria Paula Dallari. Políticas públicas: reflexões sobre o conceito jurídico. São Paulo: Saraiva, 2006. p. 39.

33 COMPARATO, Fábio Konder. Ensaio sobre o juízo de constitucionalidade de políticas públicas. São Paulo: Revista dos Tribunais, 1997. p. 737.

34 SECCHI, Leonardo. Políticas públicas: conceitos, esquemas de análise, casos práticos. 2. ed. São Paulo: Cengage Learning, 2013. p. 157. 
35 SECCHI, Leonardo. Políticas públicas: conceitos, esquemas de análise, casos práticos. 2. ed. São Paulo: Cengage Learning, 2013. p. 2.

36 Ibid., p. 43.

37 SECCHI, Leonardo. Políticas públicas: conceitos, esquemas de análise, casos práticos. 2. ed. São Paulo: Cengage Learning, 2013. p. 101.

38 CÂMARA, Guilherme Costa. Programa de política criminal: orientado para a vítima de crime. São Paulo: Revista dos Tribunais, 2008.

39 BRASIL. Decreto n ${ }^{\circ} 4.388$, de 25 de setembro de 2002. Promulga o Estatuto de Roma do Tribunal Penal Internacional. Presidência da República, Brasília, DF. Disponível em: <http://www.planalto.gov.br/ccivil_03/ decreto/2002/D4388.htm >. Acesso em: 27 ago. 2016.

40 BRASIL. Decreto n ${ }^{\circ} 4.388$, de 25 de setembro de 2002. Promulga o Estatuto de Roma do Tribunal Penal Internacional. Presidência da República, Brasília, DF. Disponível em: <http://www.planalto.gov.br/ccivil_03/ decreto/2002/D4388.htm >. Acesso em: 27 ago. 2016.

41 BRASIL. Lei $\mathrm{n}^{\circ} 11.340$, de 7 de agosto de 2006. Cria mecanismos para coibir a violência doméstica e familiar contra a mulher, nos termos do $\S 8^{\circ}$ do art. 226 da Constituição Federal, da Convenção sobre a Eliminação de Todas as Formas de Discriminação contra as Mulheres e da Convenção Interamericana para Prevenir, Punir e Erradicar a Violência contra a Mulher; dispõe sobre a criação dos Juizados de Violência Doméstica e Familiar contra a Mulher; altera o Código de Processo Penal, o Código Penal e a Lei de Execução Penal; e dá outras providências. Presidência da República, Brasília, DF. Disponível em: <http://www.planalto.gov.br/ ccivil 03/ ato2004-2006/2006/lei/111340.htm >. Acesso em: 27 jun. 2016.

42 BRASIL. Lei n ${ }^{\circ} 11.340$, de 7 de agosto de 2006. Cria mecanismos para coibir a violência doméstica e familiar contra a mulher, nos termos do $\S 8^{\circ}$ do art. 226 da Constituição Federal, da Convenção sobre a Eliminação de Todas as Formas de Discriminação contra as Mulheres e da Convenção Interamericana para Prevenir, Punir e Erradicar a Violência contra a Mulher; dispõe sobre a criação dos Juizados de Violência Doméstica e Familiar contra a Mulher; altera o Código de Processo Penal, o Código Penal e a Lei de Execução Penal; e dá outras providências. Presidência da República, Brasília, DF. Disponível em: <http://www.planalto.gov.br/ ccivil_03/_ato2004-2006/2006/lei/111340.htm>. Acesso em: 27 jun. 2016.

43 BRASIL. Lei $\mathrm{n}^{\circ} 11.340$, de 7 de agosto de 2006. Cria mecanismos para coibir a violência doméstica e familiar contra a mulher, nos termos do $\S 8^{\circ}$ do art. 226 da Constituição Federal, da Convenção sobre a Eliminação de Todas as Formas de Discriminação contra as Mulheres e da Convenção Interamericana para Prevenir, Punir e Erradicar a Violência contra a Mulher; dispõe sobre a criação dos Juizados de Violência Doméstica e Familiar contra a Mulher; altera o Código de Processo Penal, o Código Penal e a Lei de Execução Penal; e dá outras providências. Presidência da República, Brasília, DF. Disponível em: <http://www.planalto.gov.br/ ccivil_03/_ato2004-2006/2006/lei/111340.htm>. Acesso em: 27 jun. 2016.

44 SUXBERGGER, Antonio Henrique Graciano. O Sistema Inglês. In: ÁVILA, Thiago André Pierobom de et al. Modelos Europeus de enfrentamento à violência de gênero: experiências e representações sociais. Brasília: ESMPU, 2014. p. 355.

45 BRASIL. Lei $\mathrm{n}^{\mathrm{O}}$ 11.340, de 7 de agosto de 2006. Cria mecanismos para coibir a violência doméstica e familiar contra a mulher, nos termos do $\S 8^{\circ}$ do art. 226 da Constituição Federal, da Convenção sobre a Eliminação de Todas as Formas de Discriminação contra as Mulheres e da Convenção Interamericana para Prevenir, Punir e Erradicar a Violência contra a Mulher; dispõe sobre a criação dos Juizados de Violência Doméstica e Familiar contra a Mulher; altera o Código de Processo Penal, o Código Penal e a Lei de Execução Penal; e dá outras providências. Presidência da República, Brasília, DF. Disponível em: <http://www.planalto.gov.br/ ccivil_03/_ato2004-2006/2006/lei/111340.htm>. Acesso em: 27 jun. 2016.

46 BRASIL. Lei no 11.340 , de 7 de agosto de 2006. Cria mecanismos para coibir a violência doméstica e familiar contra a mulher, nos termos do $\S 8^{\circ}$ do art. 226 da Constituição Federal, da Convenção sobre a Eliminação de Todas as Formas de Discriminação contra as Mulheres e da Convenção Interamericana para Prevenir, Punir e Erradicar a Violência contra a Mulher; dispõe sobre a criação dos Juizados de Violência Doméstica e Familiar contra a Mulher; altera o Código de Processo Penal, o Código Penal e a Lei de Execução Penal; e dá outras providências. Presidência da República, Brasília, DF. Disponível em: <http://www.planalto.gov.br/ ccivil_03/_ato2004-2006/2006/lei/111340.htm >. Acesso em: 27 jun. 2016. 
47 BRASIL. Lei n ${ }^{\circ}$ 11.530, de 24 de outubro de 2007. Institui o Programa Nacional de Segurança Pública com Cidadania - PRONASCI e dá outras providências. Presidência da República, Brasília, DF. Disponível em: <http://www.planalto.gov.br/ccivil_03/_ato2007-2010/2007/Lei/L11530.htm>. Acesso em: 27 jun. 2016.

48 BASTOS, Elísio Augusto Velloso. $\bar{A}$ importância da Cidadania na definição e na implementação de políticas públicas. In: MORAES, Alexandre de; KIM, Richard Pae. Cidadania: o novo conceito jurídico e a sua relação com os direitos fundamentais individuais e coletivos. São Paulo: Atlas, 2013. p. 146.

49 COUTINHO, Diogo R. O direito nas políticas públicas. In: MARQUES, Eduardo; FARIA, Carlos Aurélio Pimenta de. Política Pública como campo disciplinar. São Paulo: Unesp; Rio de Janeiro: Fiocruz, 2013.

50 DANTAS, Francisco Clementino de San Tiago. A educação jurídica e a crise brasileira. 1955, p. 452 apud COUTINHO Diogo R. O direito nas políticas públicas. In: MARQUES, Eduardo; FARIA, Carlos Aurélio Pimenta de. Política Pública como campo disciplinar. São Paulo: Unesp; Rio de Janeiro: Fiocruz, 2013. p. 4.

51 COUTINHO, Diogo R. O direito nas políticas públicas. In: MARQUES, Eduardo; FARIA, Carlos Aurélio Pimenta de. Política Pública como campo disciplinar. São Paulo: Unesp; Rio de Janeiro: Fiocruz, 2013.p. 184.

52 BUCCI, Maria Paula Dallari. Direito administrativo e políticas públicas. São Paulo: Saraiva, 2002. p. 18.

53 COUTINHO, Diogo R. O direito nas políticas públicas. In: MARQUES, Eduardo; FARIA, Carlos Aurélio Pimenta de. Política Pública como campo disciplinar. São Paulo: Unesp; Rio de Janeiro: Fiocruz, 2013.p. 187.

54 Ibid., p. 188.

55 BUCCI, Maria de Paula Dallari. Notas para uma metodologia jurídica de análise de políticas públicas. In: FORTINI, Cristina; ESTEVES, Júlio César dos Santos; DIAS, Maria Tereza Fonseca. Políticas públicas: possibilidades e limites. Belo Horizonte: Fórum, 2008. p. 250.

56 BRASIL.Lei ${ }^{\circ}$ 11.340, de 7 de agosto de 2006. Cria mecanismos para coibir a violência doméstica e familiar contra a mulher, nos termos do $\S 8^{\circ}$ do art. 226 da Constituição Federal, da Convenção sobre a Eliminação de Todas as Formas de Discriminação contra as Mulheres e da Convenção Interamericana para Prevenir, Punir e Erradicar a Violência contra a Mulher; dispõe sobre a criação dos Juizados de Violência Doméstica e Familiar contra a Mulher; altera o Código de Processo Penal, o Código Penal e a Lei de Execução Penal; e dá outras providências. Presidência da República, Brasília, DF. Disponível em: <http://www.planalto.gov.br/ ccivil_03/_ato2004-2006/2006/lei/111340.htm>. Acesso em: 27 jun. 2016.

57 SUXBERGER, Antonio Henrique Graciano. Ministério Público e política criminal: uma segurança pública compromissada com os direitos humanos. Curitiba: Juruá, 2010. p. 123.

\title{
PUBLIC POLICIES ON THE PROTECTION OF VICTIMS: A PROPOSAL FOR AN INSTITUTIONAL ARRANGEMENT IN PUBLIC SECURITY
}

\begin{abstract}
The present article analyzes the legislative approach adopted over the last decade, in relation to public policies on the protection of victims in Brazilian Criminal Law. The research mentions the relevance of observing such public policies under an institutional arrangement in public security, in which the Brazilian Criminal Justice System does not act exclusively. This study is a biographical and documentary research on the theme, also approaching concepts from Victimology and Public Policies Studies. The article also revisits the main rights of victims stated in Brazilian Criminal
\end{abstract}


Law, in order to analyze them upon crime victims' perspective. The importance of the study consists in understanding that public policies for the promotion of the rights of victims in criminal procedure require the creation of State policies, through an operational integration and a strict inter organizational dialog among public security actors.

Keywords: Public Policies. Victimology. Institutional Arrangements.

Submetido: 29 dez. 2016

Aprovado: 31 maio 2017 